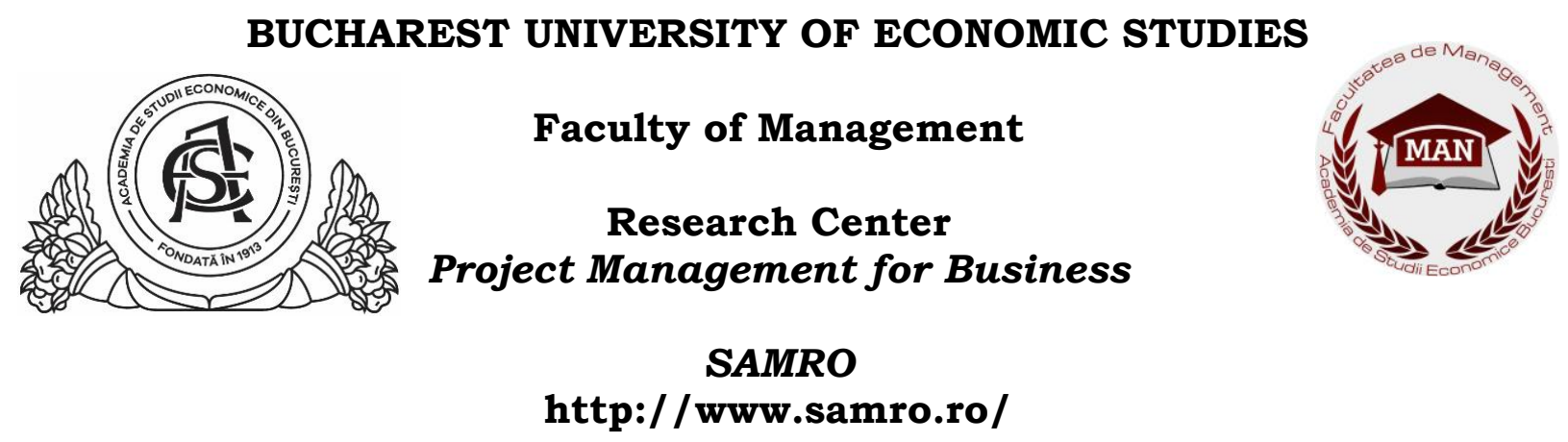

\title{
Management and Economics Review
}

\author{
Vo1. 4, Issue 2/2019 (December)
}

www.mer.ase.ro

email: mer@man.ase.ro

Bucharest

Editura ASE 


\section{Editorial board:}

Editor-in-chief: Carmen Nadia Ciocoiu Managing editor: Corina Marinescu Co-editors: Sofia Elena Colesca, Claudiu Cicea

\section{Scientific board:}

Adrian Curaj, Politehnica University of Bucharest, Romania

Aniko Csepregi, University of Pannonia, Hungary

Anne Charllote Taillandier, Universite d'Artois, France

Antonio Natera Peral, Universidad Carlos III de Madrid, Spain

Baiba Savrina, University of Latvia, Latvia

Basarab Gogoneata, The Bucharest University of Economic Studies, Romania

Catalina Crisan, Babes-Bolyai University, Romania

Catalina Radu, The Bucharest University of Economic Studies, Romania

Constantin Bratianu, The Bucharest University of Economic Studies, Romania

Corina Marinescu, The Bucharest University of Economic Studies, Romania

Cosmin Dobrin, Bucharest University of Economic Studies, Romania

Cristian Tiu, University at Buffalo, USA

Daniela Grigori, Universite Paris-Dauphine Paris 9, France

Francisco Puig, Universidad de Valencia, Spain

Ion Partachi, University of Economic Studies from Moldova, Moldova

Ion Popa, The Bucharest University of Economic Studies, Romania

Irina-Eugenia Iamandi, Bucharest University of Economic Studies, Romania

Irina Salanta, Babes-Bolyai University, Romania

Joanna Sadkowska, University of Gdansk, Poland

Jonel Subic, Institute of Agricultural Economics, Belgrad, Serbia

Lefteris Tsoulfidis, University of Macedonia, Thessaloniki, Greece

Maria da Conceição Pereira Ramos, Universidade do Porto, Portugal

Miguel Gonzalez-Loureiro, University of Vigo, Spain and Polytechnic of Porto, Portugal

Minodora Ursacescu, The Bucharest University of Economic Studies, Romania

Monica Dudian, The Bucharest University of Economic Studies, Romania

Philipe Duez, Universite d'Artois, France

Răzvan Andrei Corboș, The Bucharest University of Economic Studies, Romania

Răzvan Cătălin Dobrea, Bucharest University of Economic Studies, Romania

Roberto M. Constantino T., Metropolitan Autonomous University - X, Mexico

Salmi Mohd Isa, Graduate School of Business, Universiti Sains Malaysia, Malaysia

Sebastian Mădălin Munteanu, The Bucharest University of Economic Studies, Romania

Simona Ștefan, The Bucharest University of Economic Studies, Romania

Stephane Callens, Universite d'Artois, France

Vandana Deswal, Sheridan College, Toronto, Canada

\section{ISSN 2501-885X}

\section{Published by: Editura ASE}

Piata Romana no. 6, sector 1, code 010374 ,

Bucharest, Romania

Telephone numbers: +4(021) 319.19.00 /

ext. 146, 460

www.editura.ase.ro, editura@ase.ro

Editorial director: Simona Buşoi

Editor: Silvia Răcaru

Typesetter: Violeta Rogojan

Cover design: Livia Radu

The responsibility for opinions expressed by articles belongs to authors. 


\section{Table of contents}

Total Public Expenditure and Long-term Economic Growth in Algeria: Applied Theoretical and Empirical Approaches Using ECM

Mohamed YAGOUB

The Analysis of the Interest Cost of the Trading Companies in Serbia

Radojko LUKIC,

Dragan VOJTESKI KLJENAK

The Role of Store Atmosphere on Purchase Decision: Case of Cafes in Banda Aceh

Teuku Roli Ilhamsyah PUTRA

Cut APRILIA

Ade AULIA

The Determinants of Taiwanese's Employment and Entrepreneurial Intention in Mainland China

Jung-Jen HUANG,

Jan-Yan LIN

A study of Curtailment Behaviour in the Context of University Students

in Indonesia: The Role of Values and Norms

Nosica RIZKALLA PURNAMANINGSIH

Trihadi Pudiawan ERHAN

Big Data Analytics and Organizational Performance: A Meta-Analysis Study

Mihai BOGDAN

Anca BORZA

The Impact of Job Satisfaction On Employees' Performance:

A Case Study of Al Hayat Company - Pepsi Employees In Erbil, Kurdistan Region-Iraq163

Sabir Sadiq ABDULKHALIQ

Zrar Mohsin MOHAMMADALI

The Link Between Decision Making Process and Performance:

A Bibliometric Analysis

Ana Alexandra GORA

Evaluating the effects of an R\&D policy mix of subsidies and tax credits

Daniel NEICU 